\title{
A Discourse Research Towards News Report of Jakarta Regional Election on Media Indonesia.com and Okezone.com Published from October 2016 until April 2017
}

\author{
Ayub Dwi Anggoro, Aziz Amin, Mohd Syaiful Nizam Abu Hassan
}

\begin{abstract}
The regional head direct election in 2017 is a democratic party that will be implemented by the Jakarta community. But, the present media has its own model in the news which is broadcasted to the public. With the power to build the public opinion, media are capable of directing the votes for political purposes. Referred to Jakarta Head Election Done Jakarta in October 2016 and April 2017 at Media Indonesia.com. In the period of Seven months there are 5 (five) big issues rose in the news. Those are: issues of electability and support, campaign issues and performance, issues of blasphemy, and issues of political promises in campaigns. The research would like to examine the ideology or political interests of media.indonesia.com and okezone.com, also the works of opinion formation happened in public as well as the meanings of the news publication in the framing that is created by the media against the question of politics. This research use the qualitative approach supported by the quantitative analysis. The analysis has coverage of headline news delivered by two online media, namely mediaindonesia.com and okezone.com in the period of October until April 2017 using the method of Critical Discourse Analysis Model Teun A. Van Dijk. As for the quantitative data, a descriptive analysis using SPSS for the 1541 proclamations published by both mediaindonesia.com and okezone.com. From the above description, the hidden message is that mediaindonesia.com tends to support the pair of Basuki Tjahya Purnama (Ahok) and Djarot Saeful Hidayat. It is indicated by the proportion of publication that is mostly 564 news (56.9\%) from the total of 991 reportages are covering Basuki Tjahya Purnama (Ahok) and Djarot Saeful Hidayat, mediaindonesia.com tries to legitimize the high electability and support to the pair Basuki Tjahaja Purnama and Djarot Saeful Hidayat by appointing famous figures both among politicians and artists who provide full support for the couple. Meanwhile, okezone.com tried to give an image that the couple Anies Rasyid Baswedan and Sandiaga Salahudin Uno received great support from the community because the arrogance of the attitude carried out by the incumbent Governor Basuki Tjahaja Purnama (Ahok). From the above description, the hidden massage is that okezone.com tends to support Anies Rasyid Baswedan and Sandiaga Salahudin Uno. It is indicated by the proportion of publication that is mostly 324 news (58.9\%) from the total of 550 reportages, are covering Anies Rasyid Baswedan and Sandiaga Salahudin Uno. From these things, it can be summed up that the political news coverage scheme in an attempt to build the reputation or the candidates supported by the media. Therefore in the extention of the Teun Van Dijk concept, ideology is an independent unit that must be separated because ideology has intervened in text, cognition, and
\end{abstract}

Revised Manuscript Received on July 10, 2019

Ayub Dwi Anggoro, University Muhammadiyah of Ponorogo, Indonesia.

Aziz Amin, Faculty of Applied Social Science (FSSG), Universiti Sultan Zainal Abidin, Gong Badak Campus, 21300 Terengganu, Malaysia.

Mohd Syaiful Nizam Abu Hassan, Faculty of Applied Social Science (FSSG), Universiti Sultan Zainal Abidin, Gong Badak Campus, 21300

Terengganu, Malaysia. context. The implication of this study media should return to the journalistic ethics code in informing the public.

Index Terms:- Civic culture, Kanayatn Dayaknese society, local wisdom, Naik Dango ceremony, Saham village.

\section{INTRODUCTION}

Media as one of politics communication channel will become an interesting subject to analyze its responsibility value to the public or be a politics commodity only. Will every news or information content shared to the audiences have an objective view and educative message for public? When the media has trapped in a politics circumstance, it might be losing its ethical journalistic. In the latest politics competition in Indonesia, a central action is the role of media in building, processing and creating an opinion. Issue means not only real occurred event but also designed condition probably formed by arranging the public view. The focus is to build the idea from people, so that the figure would have a positive portray. The presidential election is now propagating through the governor election in DKI Jakarta, creating confusion towards the public disorder.

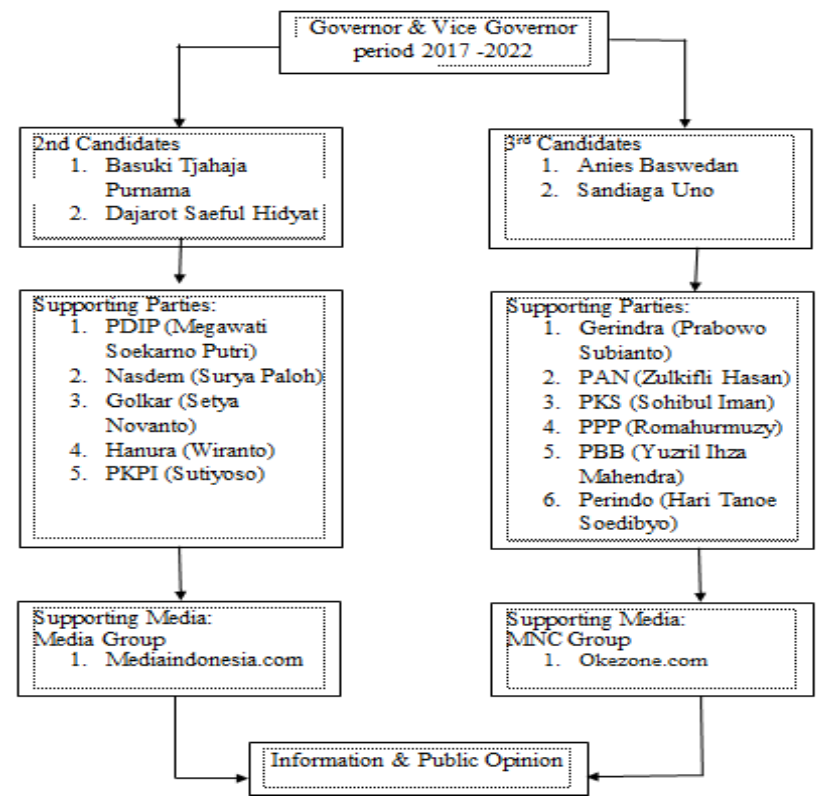

Fig. 1. A politics map of governor election in Jakarta $2^{\text {nd }}$ round 


\section{A DISCOURSE RESEARCH TOWARDS NEWS REPORT OF JAKARTA REGIONAL ELECTION ON MEDIA INDONESIA.COM AND OKEZONE.COM PUBLISHED FROM OCTOBER 2016 UNTIL APRIL 2017}

The above politics scheme (Fig. 1) has shown the battle of two major media industry in Indonesia. Media group is soon facing MNC group. The broader the network has, the more capable the media in breaking the public opinion of political preference into two perceptions. Though in the end the $3^{\text {rd }}$ candidacy Anies Baswedan and Sandiaga Uno win the public, while the second candidacy Basuki Tjahaja Purnama (Ahok) and Djarot Saeful Hidayat got $42.04 \%$ votes (Table $1)$.

Table 1: A result of governor election $2^{\text {nd }}$ round [1]

Governor and Vice Governor Candidacy of DKI Jakarta

\begin{tabular}{|c|c|}
\hline Basuki Tjahaja Purnama & Anies Baswedan \\
Djarot Saeful Hidayat & Sandiaga uno \\
\hline Result: & Result: \\
$42.99 \%$ & $57.96 \%$ \\
\hline
\end{tabular}

The news reporting of Governor Election in Jakarta from September 2016 until April 2017 at mediaindonesia.com and okezone.com by adopting the Teun Van Dijk Model Analysis and adding Ideology is identified as: How would the ideology perspective be presented at both mediaindonesia.com and okezone.com.

\section{The Evolution of Critical Discourse Analysis in the World}

Research from [2] about polarized discourse in the news stated: This study aims to investigate ideological structures of polarized discourse coded in the reports of two online news websites: egyptindependent.com and Ikhwanweb.com. The research focuses on online news reports relating to three interrelated events: the issuing of a constitutional declaration by the Egyptian president, the aftermath clashes outside the presidential palace and the issuing of the Egyptian draft constitution. The analysis of these reports is conducted within the framework of Critical Discourse Analysis. The features of the ideologies of polarized discourse are traced through quotation patterns and labeling. The study concludes with a discussion on how both websites establish a dichotomy of 'we' versus 'them.' Besides, the reports of each website marginalize the other through what is termed as 'Absent News' [3].

From the research of [4] aims to investigate three laws created during Brazilian republic government that are related to the colored population: Articles III and VIII of Criminal Code from 1890; law o quotas from 1934; and the statute of racial equality, from 2010. The theoretical referential will be critical discourse analysis (CDA), and it will rely on the work of Van Dijk and Fairclough. The purpose of this paper will problematize the myth of racial democracy through the study of intertextuality between juridical and scientific discourse and defend the hypothesis that the myth is both a way to restrain ethnic conflicts and also a mechanism of domination, but it is not a representation of Brazilian reality.

\section{News and Online Journal}

In [5] defined news in his book, Here the News, as new information about an important event and attract the interest of audiences [6]. In [7] wrote in his book (Reporting News), the news is the fastest report about fact or opinions for both competition with the percentage of $57.96 \%$ votes from the

are important to majority people [6]. News is one of the journalistic works that is written based on evidence or real problem or simplifying as the report of a new event. Not all of the events need to be documented, only ones that meet the criteria and have a value [8]. While, in [9] identified news. As anything that public need and want to know genuinely [10].

Mass media gives information to public anything they would need. From the above definition, we can conclude that news is the fastest report of fact, new idea, exciting or important for most people through the newspaper, radio, television, and online media [10]. The writing and delivery of the online press are almost similar to the writing of printed media, especially newspaper. But, the difference lies in the publication media which is the internet. Generally, when the online news is being opened, title and highlight are the only that can be seen. The reader has to click on the link to read the details of the news passage [11].

\section{Critical Discourse Analysis}

Van Dijk viewed CDA as research of discourse analysis mainly discuss how social power abuse and inequality is being portrayed, reproduced, and rejected by the text and conversation in the context of social and politics. CDA takes a clear position to understand, expose, then challenge social inequality. As a result, CDA is known for its characteristics as an analysis tool that carries out social politics movement [12].

According to van Dijk, research on discourse is not enough based solely on text analysis, because the text is only the result of a production practice that must also be observed. Here must also be seen how a text is produced. The production process involves a process called social cognition. Text is formed in a discourse practice, a practice of discourse. Here there are two parts, namely micro text which represents a topic of issues in the news, and a large element in the form of social structures. Van Dijk makes a bridge that connects a large element in the form of a social structure with elements of micro discourse with a dimension called social cognition. Social cognition has two meanings. On the one hand, it shows how the process of the text is produced by journalists/media, on the other hand, it describes the values of the society that are spread and absorbed by journalist cognition and finally used to make news texts [13].

\section{METHODOLOGY}

This research is qualitative research that is a field of stand-alone investigation; this research alludes to various scientific disciplines, fields, and themes. The same set of terms, complex and interrelated concepts and assumptions envelops with regard to qualitative research. The family includes traditions that are closely related to positivism, Post Structuralism, and various points of view or methods, qualitative research that is linked to cultural studies and interpretative features [14]. Besides, this research is also supported by using quantitative data which leads to data 
processing through SPSS to find out the percentage and comparison between research objects to be descriptive.

This type of research uses a qualitative descriptive approach (Table 2). This approach is a research procedure that produces descriptive data that produces written or verbal words from people and observable behavior [15]. This study took the Object 1541 Title of DKI Jakarta Direct Local Election Reporting about candidates for governor and deputy governor from October 1st 2016 to April 15th 2017, at Mediaindonesia.com and Okezone.com. The steps to conduct an analytical study on the preaching of the DKI Jakarta direct regional elections in 2017 are as follows:

a. Analyze ideologies classified through positive and negative news images in the category of issues raised by the media including issues of Electability and support, Campaign Issues and performance, Issues of blasphemy, Issues of Political Promises in campaigns, through processing quantitative data using SPSS.

b. Conduct analysis using the Van Dijk critical discourse analysis model on text, cognition, and context.

Table 2: Critical discourse analysis method [13]

\begin{tabular}{|l|l|}
\hline \multicolumn{1}{|c|}{ Text } & \multicolumn{1}{|c|}{ Method } \\
\hline $\begin{array}{l}\text { Analyze how the discourse } \\
\text { strategy or textual written in the } \\
\text { news at } \\
\text { mediaindonesia.com and } \\
\text { okezone.com }\end{array}$ & Critical linguistics \\
\hline \multicolumn{2}{|c|}{ Social Cognition } \\
$\begin{array}{l}\text { Analyze the form of cognition } \\
\text { in publication } \\
\text { mediaindonesia.com at and } \\
\text { okezone.com }\end{array}$ & $\begin{array}{l}\text { Historical } \\
\text { publication } \\
\text { mediaindonesia.com and } \\
\text { okezone.com }\end{array}$ \\
$\begin{array}{l}\text { Analyze the news publication } \\
\text { from October 2016 to April } \\
\text { 2017 at mediaindonesia.com } \\
\text { and okezone.com }\end{array}$ & Literature study and \\
historical search \\
\end{tabular}

\section{RESULTS AND DISCUSSION}

The Comparison of Reputation on News Publication at Mediaindonesia.com and Okezone.com

The mediaindonesia.com is an online media that massively report the phenomenon of Regional Head Election of DKI Jakarta as mentioned in Table 3 below. During the period of the campaign, in October 2016 to April 2017, it had published 991 news related to the candidates of the Governor Election in Jakarta in 2017 are as follows:

1. The candidate pair No. 1 Agus Harimurti Yudhoyono and Sylviana Murni

2. The candidate pair No. 2 Basuki Tjahaja Purnama and Djarot Saeful Hidayat

3. The candidate No. 3 Anies Rasyid Baswedan and Sandiaga Salahudin Uno

The news publication delivered through mediaindonesia.com was a crucial step in a competition to reach the power of DKI Jakarta. The political strategy war to seize the sympathy and support from citizens of Jakarta has heated the political escalation. The Governor Election process is dividing the public into two fortresses, and making it an intense conflict of a national issue. The most dangerous conflict in Indonesia was when it is offending a forbidden issue of ethnicity, religion, and race (Suku, Agama, dan Ras - SARA). The conflict will eventually trigger the war inside of Indonesia as the country has a heterogenic society.

Table 3: Monthly news publication at mediaindonesia.com

\begin{tabular}{|c|c|c|}
\hline Month & Frequency & Percentage \\
\hline October 2016 & 214 & 21.6 \\
\hline November 2016 & 271 & 27.3 \\
\hline December 2016 & 215 & 21.7 \\
\hline January 2017 & 98 & 9.9 \\
\hline February 2017 & 113 & 11.4 \\
\hline March 2017 & 61 & 6.2 \\
\hline April 2017 & 19 & 1.9 \\
\hline Total & 991 & 100.0 \\
\hline
\end{tabular}

Table 3 has shown that in October 2016, mediaindonesia.com broadcasted 214 news headlines, had increased in November to 271 headlines, decreased again in December for 215 news, in January 2017 fallen down to only 98 news, 113 headlines in February, in March and April has counted 61 news and 19 headlines consecutively. From the total of news publication during the available period, news produced in November recorded the highest frequency of broadcast as much as 271 news shared to the public.

Table 4 has shown the frequency of news reportage at mediaindonesia.com has been classified into three topics of inclination for candidates of Governor in a Regional Head Election of DKI Jakarta. Agus Harimurti Yudhoyono and Sylviana Murni yielded 183 publications, Basuki Tjahaja Purnama, and Djarot Saeful Hidayat got the most headlines frequency with a total of 564 coverages, while Anies Rasyid Baswedan and Sandiaga Salahudin Uno reached 244 broadcasts moderately. From the above analysis, Basuki and Djarot have the largest proportion of news publication at mediaindonesia.com during the campaign period in table 5.15 ; reaching $56.9 \%$ of the total reportage by mediaindonesia.com, Anies, and Sandiaga reaching 24.6\%; and only as much as $18.5 \%$ of the total coverages are mentioning Agus and Sylviana.

\section{Table 4: Candidateship (reputation in news frequency} published by mediaindonesia.com)

\begin{tabular}{|c|c|c|}
\hline Candidates & Frequency & Percentage \\
\hline $\begin{array}{c}\text { Agus Harimurti Yudhoyono and } \\
\text { Sylviana Murni }\end{array}$ & 183 & 18.5 \\
\hline $\begin{array}{c}\text { Basuki Tjahaja Purnama and Djarot } \\
\text { Saeful Hidayat }\end{array}$ & 564 & 56.9 \\
\hline $\begin{array}{c}\text { Anies Rasyid Baswedan and } \\
\text { Sandiaga Salahudin Uno }\end{array}$ & 244 & 24.6 \\
\hline Total & 991 & 100.0 \\
\hline \multicolumn{2}{|c|}{} \\
\hline
\end{tabular}




\section{A DISCOURSE RESEARCH TOWARDS NEWS REPORT OF JAKARTA REGIONAL ELECTION ON MEDIA INDONESIA.COM AND OKEZONE.COM PUBLISHED FROM OCTOBER 2016 UNTIL APRIL 2017}

The news reportage of candidate pair by mediaindonesia.com is including the central issue portrayed the momentum of economics, political, social, and cultural situation related to the direct election and activities of the contestants in a democracy battle in Jakarta. The issues brought up by mediaindonesia.com has been classified into:

1. The issue of electability and endorsement

2. The issue of campaign and performance accomplishment

3. The issue of religion blasphemy

4. The issue of political promises.

The headline publication by mediaindonesia.com in October 2016 - April 2017 for electability and endorsement issue has recorded as much as 159 news, while issue of campaign and performance for 675 articles, religion blasphemy issue is documented in 69 news, and political promises for 88 coverages. From the above frequency, the issue of campaign and achievement has domineering the publication for $68.1 \%$; electability and endorsement for $16 \%$; political promises for $8.9 \%$; and lastly $7 \%$ dedicated to sharing the religion blasphemy issues (Table 5).

Table 5: Issue of news imaging at Mediaindonesia.com

\begin{tabular}{|c|c|c|}
\hline Issue & Frequency & Percentage \\
\hline $\begin{array}{c}\text { The issue of Electability and } \\
\text { Endorsement }\end{array}$ & 159 & 16.0 \\
\hline $\begin{array}{c}\text { The issue of Campaign and } \\
\text { Performance }\end{array}$ & 675 & 68.1 \\
\hline The issue of Religion Blasphemy & 69 & 7.0 \\
\hline The issue of Political Promises & 88 & 8.9 \\
\hline Total & 991 & 100.0 \\
\hline
\end{tabular}

The rise of reportage has brought up the image or reputation for the subject of the passages. In the news publication at mediaindonesia.com covering the election in Jakarta during the period of campaign October 2016 to April 2017 has introduced image or reputation. Good news should have a balance for every news resources to be produced or in a simple word it should be neutral, not having labeled as media interpretation of the positive and negative image certain figure without reliable and valid reference.

In term of publication management, mediaindonesia.com has resulted in image identification, the positive image has come from as good as 660 news, 112 news for negative issues, while the neutral image has come from 219 news. In percentage, mediaindonesia.com broadcasted mostly $66.6 \%$ positive image, $22.1 \%$ of the neutral image and $11.3 \%$ of the negative image containing the Regional Head Election of DKI Jakarta.

Table 6: Image or reputation publication at mediaindonesia.com

\begin{tabular}{|c|c|c|}
\hline Reputation & Frequency & Percentage \\
\hline Positive & 660 & 66.6 \\
\hline Negative & 112 & 11,3 \\
\hline Neutral & 219 & 22.1 \\
\hline Total & 991 & 100.0 \\
\hline
\end{tabular}

From the above description (Table 6), the hidden message is that mediaindonesia.com tends to support the pair of
Basuki and Djarot. It is indicated by the proportion of publication that is mostly 564 news from the total of 991 reportages are covering Basuki Tjahya Purnama and Djarot Saeful Hidayat.

Reputation in a News Publication at Okezone.com Referring to the Candidateship of Governor Election in Jakarta 2017

An online media is the best channel so far; it could be a friend or enemy for people in the circle. The political world has become an exciting object of information to trail that public can access it through any media, anywhere, anytime. The Regional Head Election of DKI Jakarta has been one of the critical moment to be followed its progress. In a daily format, media are always sharing the latest situation or issue of candidates, campaign, endorsement, etc. Most of the issue is intended to build up the reputation or weaken the image of a competitor. As usual, they have hidden organizational motives related to their goal of the political party.

Table 7: Monthly reputation in news publication at okezone.com

\begin{tabular}{|c|c|c|}
\hline Month & Frequency & Percentage \\
\hline October 2016 & 87 & 15.8 \\
\hline November 2016 & 51 & 9.3 \\
\hline December 2016 & 41 & 7.5 \\
\hline January 2017 & 126 & 22.9 \\
\hline February 2017 & 66 & 12.0 \\
\hline March 2017 & 134 & 24.4 \\
\hline April 2017 & 45 & 8.2 \\
\hline Total & 550 & 100.0 \\
\hline
\end{tabular}

Table 7 has shown that the okezone.com published a total of 550 news reportages in seven months. The frequency of news coverage at okezone.com is less than mediaindonesia.com; almost half of the mediaindonesia.com records of broadcasts is referring to the three pairs. At okezone.com, the reportage mostly take place in March 2017 for 134 news been broadcasted ( $24.4 \%$ of total news), in October 2016 for 87 news with percentage of $15.8 \%$; in November 2016 as much as 51 new for $9.3 \%$; in December had decreased to 41 news or equals to $7.5 \%$; in February 2017 had increased a bit of 66 news (12\%); and in April 201745 news $(8.2 \%)$ from the total reportages.

As much as 550 reportages had been delivered through okezone.com in October 2016 to April 2017 have missions asserted to it, both the organizational purpose or purely information broadcast for the public concerning the Regional Head Election of DKI Jakarta 2017. By that means, anything that has done by the six candidates of Governor and Vice of Governors gets the spotlight from all media positively or negatively. 
Table 8: Candidacy (image on news issue at okezone.com)

\begin{tabular}{|c|c|c|}
\hline Candidate & Frequency & Percentage \\
\hline $\begin{array}{c}\text { Agus Harimurti Yudhoyono and } \\
\text { Sylviana Murni }\end{array}$ & 88 & 16.0 \\
\hline $\begin{array}{c}\text { Basuki Tjahaja Purnama and } \\
\text { Djarot Saeful Hidayat }\end{array}$ & 138 & 25.1 \\
\hline $\begin{array}{c}\text { Anies Rasyid Baswedan and } \\
\text { Sandiaga Salahudin Uno }\end{array}$ & 324 & 58.9 \\
\hline Total & 550 & 100.0 \\
\hline
\end{tabular}

In Table 8, there were three candidate-pair of Governor and Vice of Governor Election in DKI Jakarta 2017, Agus Harimurti Yudhoyono and Sylviana Murni (candidacy number 1), Basuki Tjahaja Purnama and Djarot Saeful Hidayat (candidacy number 2), and Anies Rasyid Baswedan and Sandiaga Salahudin Uno (candidacy number 3). From the total of 550 news covered at okezone.com; 88 news or $16 \%$ from that talked about candidacy number 1 Agus Harimurti Yudhoyono and Sylviana Murni. Candidacy number 2 Basuki Tjahaja Purnama and Djarot Saeful Hidayat have the quota of 138 reportages or $25.1 \%$ of the total. And the candidacy number 3 Anies Rasyid Baswedan and Sandiaga Salahudin Uno have the most coverages with the proportion of 324 news $(58.9 \%)$ from the total.

Table 9: Issue of news imaging at okezone.com

\begin{tabular}{|c|c|c|}
\hline Issue & Frequency & Percentage \\
\hline $\begin{array}{c}\text { The issue of Electability and } \\
\text { Endorsement }\end{array}$ & 82 & 14.9 \\
\hline $\begin{array}{c}\text { The issue of Campaign and } \\
\text { Performance }\end{array}$ & 394 & 71.6 \\
\hline The issue of Religion Blasphemy & 26 & 4.7 \\
\hline The issue of Political Promises & 48 & 8.7 \\
\hline Total & 550 & 100.0 \\
\hline
\end{tabular}

The issues certainly are enlivening the publication at okezone.com from October 2016 to April 2017. From Table 9 , the media recorded to have 82 news $(14.9 \%)$ reportage containing issue of electability and endorsement, and 48 $(8.7 \%)$ of the total covered about political promises. In contrary, the highest point at 394 news $(71.6 \%)$ talked about campaign and performance, while the lowest point of 26 news $(4.7 \%)$ highlighted the religion blasphemy. The issue of campaign and performance has become the full attention for news publication at okezone.com.

Table 10: Reputation (reputation on news publication at okezone.com)

\begin{tabular}{|c|c|c|}
\hline Reputation & Frequency & Percentage \\
\hline Positive & 285 & 51.8 \\
\hline Negative & 67 & 12.2 \\
\hline Neutral & 198 & 36.0 \\
\hline Total & 550 & 100.0 \\
\hline
\end{tabular}

Table 10 has shown that Okezone.com has produced news with a positive image attached to it for 285 articles (51.8\%) from the total produced articles. The positive image framing is directed to the pair of Anies and Sandiaga and only a few for Agus and Sylviana. And not surprisingly, there is no positive image directed to Basuki and Djarot. For the negative issues took 67 news or $12.2 \%$ of the total, aimed at Basuki and Djarot. While, the neutral reputation are produced at 198 news or $36 \%$ of the total coverages.

Analysis of Teun Van Dijk Model at Mediaindonesia.com and Okezone.com

\section{a Mediaindonesia.com}

\section{Text Macro}

1. The results of the identification and elaboration contained in a publication by mediaindonesia.com in October 1st 2016 to April 15th 2017 is related to the title and content of the above reportage with the theme of issues of Electability and Endorsement. campaign and Performance, Religion Blasphemy, and issues of Political Promises. The issues are infused in the campaign message against pairs of serial numbers 1 (one) Agus Yudhoyono and Sylviana Murni

2. The results of news observation for Mediaindonesia.com in October 1st 2016 to April 15th 2017 is related to the title and content of the above news theme on the issue of Electability and Endorsement, Campaign and Performance, Political Promises in the campaign against pair number 2 (two ) Basuki Tjahaja Purnama and Djarot Saeful Hidayat.

3. The results of the analysis on the news carried out by Mediaindonesia.com in October 1st 2016 to April 15th 2017 related to the title and content of the above news with the theme of issues of Electability and Endorsement, Campaign and Performance, Political Promises. The issues are embedded in the campaign against pair number 3 (three) Anies Baswedan Sandiaga Uno.

\section{Text Superstructure}

1. The results of the identification and elaboration of the news carried out by mediaindonesia.com emphasized the title and news content scheme which informed the condition of the electability position of Agus Yudhoyono and Sylviana Murni, the conditions of the candidate pair supporters, and political promises to be made, while the news content who uses an inverted pyramid scheme. For lead / terrace news is described about the atmosphere not so developed electability progress and lack of solid support groups, criticism of Ahok's performance and political promises For body news, supporting information, chronological and additional data written by quoting statements from news sources informing about answers on developing issues and work plans.

2. The results of the elaboration of the news published by Mediaindonesia.com emphasized the title and news content scheme that informed the condition of the electability position of Basuki Tjahaja Purnama and Djarot Saeful Hidayat, the conditions of the candidate pair supporters, and political promises to be made, while content of news tuses an inverted pyramid

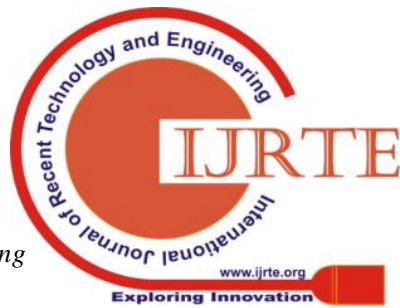




\section{A DISCOURSE RESEARCH TOWARDS NEWS REPORT OF JAKARTA REGIONAL ELECTION ON MEDIA INDONESIA.COM AND OKEZONE.COM PUBLISHED FROM OCTOBER 2016 UNTIL APRIL 2017}

scheme. The lead or terrace news described about the atmosphere of not so developed electability progress and lack of solid support groups, criticism of Ahok's performance, and political promises. As for body news, supporting information, chronological, and additional data written by quoting statements from news sources informing about answers on developing issues and work plans to be carried out.

3. The results of the elaboration on the news carried out by Mediaindonesia.com emphasized the title and news content scheme that informed the condition of the electability position of Anies Baswedan - Sandiaga Uno, the conditions of the candidate pair supporters, and political promises to be made, while the contents of the news use an inverted pyramid scheme. The lead or terrace news described about the atmosphere of not so developed electability progress and lack of solid support groups, criticism of Ahok's performance and political promises. As for body news, supporting information, chronological, and additional data written by quoting statements from news sources informing about answers on developing issues and work plans to be carried out.

\section{Text Micro}

1. The results of Semantic Analysis, Syntax, Stylistics, and Rhetoric often use parallelism and repetition of language styles. Parallelism is a style of language in the form of alignment between phrases that occupy the same function; repetition is a style of language by repeating the use of certain words or groups of words while language rhetoric tends to use deliberative rhetoric focusing on what will happen later when a policy is applied now.

\section{Social Cognition}

Journalists and editors of Mediaindonesia.com are members of the Media Group. The media group consists of Media Indonesia (Mediaindonesia.com), Lampung Post, Borneo news, Tabloid Prioritas, and Metro TV. The ownership of the media group is Surya Paloh who is also the chairman of the Democratic National party.

\section{Social Context}

The news coverage was published by Mediaindonesia.com in October 1st 2016 to April 15th 2017 with campaign issues and performance reported on three events:

\section{a. Agus Yudhoyono and Sylviana Murni}

1. The first event was Susilo Bambang Yudhoyono who led the Agus - Sylviana volunteer consolidation meeting.

2. The second event, the general chairman of the Cikeas Axis party (Partai Poros Cikeas) coalition of four party's leader, will go down the mountain (take an action) for the sake of candidate pair Agus - Sylviana.

3. The third event, Agus considers that Pilkada is a sacred duty call.

\section{a. Basuki Tjahaja Purnama and Djarot Saeful Hidayat}

1. The first event was the victory of Ahok in the first round of election.

2. The second event of Ahok's electability is further ahead

3. The first event concerning the high electability and support for the candidate pair Ahok-Djarot.

4. The split of supporters of the pair Agus Harimurti Yudhoyono and Sylviana Murni in the second round.

\section{a. Anies Rasyid Baswedan - Sandiaga Uno}

1. The direct campaign events for candidates for AniesSandiaga.

2. The Prabowo's guerrilla (blusukan) strategy by visiting the aquarium camp and inviting people to support the candidate pair Anies-Sandiaga.

The moment when Anies-Sandiaga is superior in the Jakarta Regional Election 2017.

b. Okezone.com

\section{Text Macro}

1. The result of the elaboration on the news reported by okezone.com in October 1st 2016 to April 15th 2017 is related to the title and content of the above news with the theme of the issue of Electability and Endorsement, Campaign and Performance, and Political Promises. These are all included in the campaign for pair number 1 (one) Agus Yudhoyono and Sylviana.

2. The results of the identification on the news carried out by okezone.com in October 1st 2016 to April 15th 2017 is related to the title and content of the above news with the theme of issues of Electability and Endorsement, Campaign and Performance, and Political Promises in the campaign for pair numbers 2 Basuki Tjahaja Purnama and Djarot Saeful Hidayat.

3. The results of the analysis on the news carried out by okezone.com in October 1st 2016 to April 15th 2017 related to the title and content of the above news with the theme of issues of Electability and Endorsement, Campaign and Performance, Political Promises. The issues are embedded in the campaign against pair number 3 (three) Anies Baswedan - Sandiaga Uno.

\section{Text Superstructure}

The results of the elaboration on the news delivered by Okezone.com emphasized the title and news content scheme that informed the condition of the electability position of Agus Yudhoyono and Sylviana Murni, the conditions of the candidate pair's supporters, and political promises to be made, while the contents of the news using an inverted pyramid scheme. The lead or terrace news described about the atmosphere of not so developed electability progress and lack of solid support groups, criticism of Ahok's performance, and political promises. As for body news, supporting information, chronological, and additional data written by quoting statements from news sources informing about answers on developing issues and work plans to be carried out. 


\section{Text Mirco}

The results of Semantic Analysis, Syntax, Stylistics, and Rhetoric often use parallelism and repetition language styles. Parallelism is a style of language in the form of alignment between phrases that occupy the same function. Repetition is a style of language by repeating the use of certain words or group of words while language rhetoric tends to use deliberative rhetoric focusing on what will happen later when a policy is implemented.

\section{Social Cognition}

The okezone.com is an entity from MNC Group owned by CEO Hary Tanoesoedibjo, a general chairman of the Perindo party who has a political tendency towards prospective candidacy of Anies Baswedan and Sandiaga Uno.

\section{Social Context}

The news background that was pointed out by Okezone.com in October 1st 2016 to April 15th 2017with electability issues and endorsement occurring in:

\section{a. Agus Yudhoyono and Sylviana Murni}

1. The events of many public figures supporting the Agus-Sylviana candidacy.

2. The voting result in the first round is unfavorable for candidate pair Agus-Sylviana because lack of electability publication.

\section{a. Basuki Tjahaja Purnama and Djarot Saeful Hidayat}

1. Campaign events prior to the selection of the first round of election.

2. Events of support and electability of Ahok in the midst of cases of blasphemy that are taking place.

3. There are still many reports about the issue of the blasphemy of the prospective Governor Ahok

4. The second round of direct election is getting more interesting.

\section{a. Anies Rasyid Baswedan - Sandiaga Uno}

1. The amount of support given to Anies - Sandiaga and the magnitude of both individual electabilities.

2 . The direct campaign and guerilla visit to the village events by candidate Anies and Sandiaga.

3. The electability of Anies and Sandiaga has increase due to Ahok's religion blasphemy case.

The event of Anies and Sandiaga won the DKI Jakarta Regional Head Election in 2017 and elected as the new Leader of Jakarta.

\section{Theoretical Analysis}

\section{Theoretical Analysis}

The ideology analysis referred by Van Dijk in a dimension analysis of text, cognition, and context will be changed in the current situation of Indonesia. The adjustment happens because the ideology becomes one-full dimension as a unit of analysis. The latest phenomenon occurred in Indonesia is how many people, the owner of media publisher, that have entering the politics and using their corporation to support their political desire. The news publication at mediaindonesia.com has defining ideology as the desire towards economics, politics, social and culture of the media corporation. In making the analysis, the dimension cannot be mixed because ideology is a large unit and has a strong influence. A statement from Widy D. Indiantari strengthens the opinion, an editor of legal and security politics at mediaindonesia.com stated that:

"Mediaindonesia.com indeed leaning to the candidacy of Ahok-Djarot because the company wants to give educative information to the public whose they are proven as the best candidates having great achievements in leading DKI Jakarta. It is true that all of the candidates are a good person, but once again we want to assist public to be as wise as possible in using their voting rights, not to be affected by reportage or invalid issues.

Moreover, the majority of the citizens still easily influenced or provoked by the unreliable source of information, or they might believe in the programs proposed by other pairs of the candidate in which the success ratio of the plan is still in question. It differs from Ahok-Djarot, who is always showing remarkable progress. And some of the political campaign delivered by other party had offended issue of religion and tribe as what is happened yesterday."

\section{Analysis of Media Condition}

Based on the further analysis, the involvement phenomenon of the media industry in a political realm truly exists and real. The function of media is a tool of propaganda by the political elite in building the political desire to a good image and opinion in the eyes of the public. The mediaindonesia.com has priority to win the AhokDjarot pair. In contrast to that, okezone.com has the urge to bring Anies-Sandiaga pair to the chair of Governor in DKI Jakarta 2017-2022. The pattern is to play and manage events into issues that will produce an image or reputation for the pair of candidates who are supported. The mediaindonesia.com in every news production carried out, gave a positive label to the pair Basuki Tjahaja Purnama and Djarot Saeful Hidayat. Never even though in the news giving a negative label or image to the pair. Whereas for the pair Agus Harimurti Yudhoyono and Sylviana Murni and Anies Rasyid Baswedan and Sandiaga Salahudin Uno dominated by negative reporting. For each news production conducted by okezone.com, giving a real label or image to the pair Agus Harimurti Yudhoyono - Sylviana Murni and Anies Rasyid Baswedan - Sandiaga Salahudin Uno, but the dominance of the percentage of news coverage was directed at supporting the couple Anies Rasyid Baswedan and Sandiaga Salahudin Uno. As for the pair Basuki Tjahaja Purnama and Djarot Saeful Hidayat, all the news publications were labeled with negative images.

The media battle scheme that took place at okezone.com was more aggressive in forming a negative image for its political opponents namely for the pair Basuki Tjahaja Purnama and Djarot Saeful Hidayat. Meanwhile, the battle at mediaindonesia.com is not so aggressive in providing a negative image for its political opponents; this is evident from the positive image that is still labeled with its political opponents namely the pair Agus Harimurti Yudhoyono Sylviana Murni and Anies Rasyid Baswedan - Sandiaga Salahudin Uno. 


\section{A DISCOURSE RESEARCH TOWARDS NEWS REPORT OF JAKARTA REGIONAL ELECTION ON MEDIA INDONESIA.COM AND OKEZONE.COM PUBLISHED FROM OCTOBER 2016 UNTIL APRIL 2017}

\section{Analysis of Society Condition}

In the news publication of Regional Head Election in DKI Jakarta 2017, the public opinions were classified into four issues as follows:

\section{a. The Electability and Support Issues}

At the mediaindonesia.com, the public had presented with news about the high electability and support of the pair Basuki Tjahaja Purnama and Djarot Saeful Hidayat. While the pair Agus Harimurti Yudhoyono - Sylviana Murni and Anies Rasyid Baswedan - Sandiaga Salahudin Uno were portrayed in the news as political figures with minimal support from the community. Also, mediaindonesia.com tries to legitimize the high electability and support to the pair Basuki Tjahaja Purnama and Djarot Saeful Hidayat by appointing famous figures both among politicians and artists who provide full support for the couple. Meanwhile, okezone.com tried to give an image that the couple Anies Rasyid Baswedan and Sandiaga Salahudin Uno received great support from the community because the arrogance of the attitude carried out by the incumbent Governor was marked by a massive public rejection of the Basuki Tjahaja Purnama and Djarot Saeful Hidayat pair.

\section{b. The Campaign and Performance Issues}

The campaign and performance issues raised by mediaindonesia.com preach and shape the image that the pair Basuki Tjahaja Purnama and Djarot Saeful Hidayat have tested their performance and need not doubt. It was evidenced by the dominance of campaign and performance issues from October 2016 - April 2017. While, for the pair Agus Harimurti Yudhoyono - Sylviana Murni and Anies Rasyid Baswedan - Sandiaga Salahudin Uno were portrayed as figures whose performance had not been tested so that the public was considered to be worried.

The news delivered by okezone.com illustrates that the pair Basuki Tjahaja Purnama and Djarot Saeful Hidayat were couples who built Jakarta arrogantly. The community is viewed as disappointed with their leadership. Meanwhile, the pair Agus Harimurti Yudhoyono - Sylviana Murni and Anies Rasyid Baswedan - Sandiaga Salahudin Uno were chosen as partners who gave new hope to the people of DKI Jakarta who needed more humanist leaders. It was reaffirmed in the second round of the Jakarta regional election after the election of two candidate pairs who fought Anies Rasyid Baswedan, and Sandiaga Salahudin Uno was described as ideal figures depicted as bringing together all elements of the Jakarta community.

\section{c. $\quad$ The Religion Blasphemy Issues}

In the news carried out by mediaindonesia.com, the Basuki Tjahaja Purnama over the blasphemy case from his speech at the Thousand Islands (Pulau Seribu) was considered in the news of mediaindonesia.com that was not true or an event ridden by political interests. The pattern used is utilizing Islamic figures both from mass organizations or political parties that reinforce the statement that what Basuki Tjahaja Purnama did was not an act of defamation of religion especially Basuki Tjahaja Purnama movement that took place in Jakarta demanding the trial of

had apologized to Muslims so that as a good Muslim should have to forgive what have done by Basuki Tjahaja Purnama.

Meanwhile, okezone.com stated that Basuki Tjahaja Purnama had committed blasphemy. The issue was reinforced by the high coverage of the mass movements which made demands to try and imprison Basuki Tjahaja Purnama.

\section{a. The Political Promises Issues}

In the news carried out by mediaindonesia.com, the figures of the pair Basuki Tjahaja Purnama and Djarot Saeful Hidayat were portrayed as figures that did not carry out many political promises but had been tested for leadership in Jakarta and had made many good changes by the people of Jakarta. Whereas the news carried out by okezone.com depicts the figures of Basuki Tjahaja Purnama and Djarot Saeful Hidayat as arrogant leaders while Anies Rasyid Baswedan and Sandiaga Salahudin Uno are portrayed as leaders who have programs that will improve the welfare of the people of Jakarta and make DKI Jakarta a more humanist capital.

\section{CONCLUSION}

The identification analysis carried out at mediaindonesia.com in October related to the issue of electability and supported in the DKI Jakarta Pilkada against the three pairs of candidates who will compete are described as follows:

a. The text dimension at mediaindonesia.com tries to build a text structure that is focused on creating the Ahok - Djarot pair reputation more positively than the other two partners. It was further reinforced by the comparison of the number of news available, where the Ahok-Djarot pair dominated the news. The okezone.com on the other hand represents the pair Anies Rasyid Baswedan and Sandiaga Salahudin Uno.

b. The cognition dimension of mediaindonesia.com has a strong affiliation with the Media Group owned by Surya Paloh, one of the Democratic National party leaders who support the nomination of the Ahok Djarot pair, while okezone.com is under the auspices of Hari Tanoesoedibjo of MNC Group and Perindo party leader.

c. The context dimension concerns about building an image for positive public opinion on candidates who are competing. The concern is an important matter in contestation of politics. Also, it also functioned to counter-attack the negative opinions spread by political opponents. The events at mediaindonesia.com news coincided with two momentum events, namely: the momentum of registration of regional election participants and the momentum of the emergence of issues of blasphemy which were in the public spotlight. In this case, mediaindonesia.com became a tool to redeem the growing public opinion about negative news addressed to Basuki Tjahaja Purnama (Ahok) while 
okezone.com withstand opinions to build a positive image for the couple Anies Rasyid Baswedan and Sandiaga Salahudin Uno.

d. The ideological analysis included by Van Dijk in the dimensions of text analysis, cognition, and context in current conditions of Indonesia will change. This change occurs because ideology becomes a separate dimension as a unit of analysis. The phenomenon that is happening today in Indonesia is that many media corporation owners plunge into the world of politics and use their companies for their political interests. News publication at mediaindonesia.com interprets ideology as the economic, political, social and cultural interests of the media corporation. To analyze the ideology, it cannot be mixed with another dimension. Because ideology is a large unit and has a strong enough influence.

e. In the extension of the Teun Van Dijk concept, ideology which is made into a unit to carry out the unit analysis of text, cognition and context from this discussion, illustrates that ideology is an independent unit that must be separated because ideology has intervened in text, cognition, and context.

\section{REFERENCES}

1. J. Carina, Kemenangan Telak Anies dan Sandiaga di Pilkada DKI $2017 . \quad$ Available: https://megapolitan.kompas.com/read/2017/05/01/07242091/k emenangan.telak.anies.dan.sandiaga.di.pilkada.dki.2017.

2. M. M. Eissa, "Polarized discourse in the news," ProcediaSocial and Behavioral Sciences, 134, 2014, pp. 70-91.

3. A. D. Anggoro, and A. Amin, "The development of Teun Van Dijk model: A discourse analysis towards news report of Jakarta regional election on Media Indonesia.com published from November until December 2016," Journal of Social Sciences Research, 4(12), 2018, pp. 834-840.

4. C. F. Vaz, R. P. de Valentin, and R. V. de Castro, "Color of law: Juridical discourse about colored people during Brazilian Republican government," Procedia-Social and Behavioral Sciences, 190, 2015, pp. 241-249.

5. P. D. Maeseneer, Inilah Berita, Pedoman Pemberitaan Radio. Alih Bahasa Ari R. Maricar dkk. Jakarta: AIBDHPPI-The Ford Foundation, 1999.

6. E. Arifin, Broadcasting to be Broadcaster. Yogyakarta: Graha Ilmu, 2010.

7. M. V. Charnley, Reporting. New York: Holt-Reinhart and Winston, 1975.

8. A. S. Romli, and A. Syamsul, Jurnalistik Online: Panduan Praktis Mengelola Media Online. Bandung: Nuansa Cendekia, 2012.

9. D. Newsom, and J. A. Wollert, Media Writing: Preparing Information for the Mass Media. California: Wadsworth Publishing Company, 1988.

10. A. H. Sumadiria, Jurnalistik Indonesia: Menulis Berita dan Feature: Panduan Praktis Jurnalis Professional. Bandung: Simbiosa Rekatama Media, 2005.

11. Mondry, Pemahaman Teori dan Praktik Jurnalistik. Jakarta: Ghalia Indonesia. 2016.

12. T. V. Dijk, Discourse and Power. New York: Palgrave Macmillan, 2015.

13. Eriyanto, Analisis Wacana: Pengantar Analisis Teks Media. Yogyakarta: PT LKiS Pelangi Aksara, 2001.

14. D. D. Lincoln, Handbook of Qualitatieve Research Yogyakarta: Pustaka Pelajar, 2009.

15. L. Moleong, Metodelogi Penelitian Kuantitatif. Bandung: PT. Remaja Rosdakarya, 2002. 